\section{Itsereflektion renessanssi?}

Markku Lehtimäki: The Poetics of Norman Mailer's Nonfiction. Self-Reflexivity, Literary Form, and the Rhetoric of Narrative. Tampere Studies in Literature and Textuality. Tampere: Tampere University Press 2005.398 s.

"This is not to say that self-reflexivity as such is a sign of literary art" (Lehtimäki s. 67 , viite 51 ).

Norman Mailerin tuotantoa käsittelevässä väitöskirjassaan Markku Lehtimäki sijoittaa "kirjallisen nonfiktion" akselille, jonka ääripäät ovat ei-referentiaalinen fiktio ja referentiaalinen nonfiktio. Edellisen kannalta katsottuna kirjallinen nonfiktio on sukua historialliselle romaanille, joka kirjallisen nonfiktion tapaan sekoittaa fiktiivisiä ja ei-fiktiivisiä aineksia. Lehtimäen tutkimus ehdottaa Mailerin teoksia luettaviksi kirjallisina, itserefleksiivisinä nonfiktioina, joissa viittaussuhteella todellisuuteen on keskeisempi sija kuin esimerkiksi postmodernistisissa historiallisissa romaaneissa.

Mitä Lehtimäki tarkoittaa "kirjallisella" nonfiktion määreenä? Tähän tutkimus ei vastaa suoraan. Sen sijaan, että Lehtimäki määrittelisi termit, joiden avulla tiettyjen tekstuaalisten ilmiöiden kirjallista luonnetta voisi käsitellä tarkasti, hän käyttää niitä (esim. "poeticity", "novelistic", "literary", "metaphorical") vähän väliä lainausmerkeissä, ikään kuin ilmaistakseen epäilyksensä niitä kohtaan.
Tutkimuksesta ei hevin löydä väitteitä tai edes hypoteeseja siitä, mitä nonfiktion kirjalliset erityispiirteet ovat. "Intertekstuaalisuus voi olla merkki tietynlaisen nonfiktion 'kirjallisuudellisuudesta', Lehtimäki kirjoittaa (s. 243), muttei pohdi sen tarkemmin, miksi näin olisi. Jos kirjallisena piirtcenä pidetään sitä, miten teksti viittaa kirjallisiin teksteihin, kirjallinen jää edelleen määrittelemättä. Tällä perusteella nonfiktiivistä romaania ei erota kirjallisuuden väitöskirjasta. Toisaalta Lehrimäki osoittaa Mailerin toistuvasti pyrkivän kohti uutta metaforaa, joka toimisi "avaimena universumin lukossa" [sic]. Jos metafora on "viimeinen kirjallinen ase tosiasioiden masentavaa maailmaa vastaan”, kuten Lehtimäki (s. 257) kirjoittaa Joseph Tabbia lainaten, mikä rekee Mailerin etsimistä "todellisista metaforista" nimenomaan kirjallisia?

Lehtimäki käsittelee refleksiivisyyden ja itserefleksiivisyyden erilaisia ilmentymiä Mailerin tuotannossa huomattavasti tarkemmin ja monisyisemmin kuin kysymystä nonfiktion kirjallisuudellisuudesta. Hän ei pohdi kirjallisen itsereflektion erityisluonnetta yleisellä teoreettisella tasolla vaan luo kokonaiskuvaa Mailerille tyypillisistä itsereflektion muodoista.

Itsereflektio viittaa ensinnäkin siihen, miten omakuvasta luodaan yhtenäistä kokonaisuutta toisten välityksellä. Toiset ovat tällä imaginaarisella tasolla alter egoja, joista minä peilaa itseään. Mailer lukee näihin alter egoihinsa voittopuolisesti maskuliinisia taiteilijoita ja muita poikkeusyksilöitä. Lehtimäki käy läpi 
Mailerin henkilökohtaista mytologiaa, joka muun muassa "ehdottaa", että nainen on joko uhka luovalle miehelle tai - parhaimmillaan - miehen siementen passiivinen vastaanottaja (ks. 149). Lehtimäki ei ota kantaa tähän "ehdotukseen" tai pyri purkamaan Mailerin mytologian hierarkioita. Sen sijaan hän käy hienovaraisen ironisesti läpi Mailerin mittclöitä esikuviensa ja vastustajiensa kanssa. Näissä mittelöissä naurettavuus on aina lähellä: Mailer viittailee subteksteihinsä kuin Muhammed Ali iskec kehässä; Mailer vastaa tekstuaalisella itsereflektiollaan Marilyn Monroen seksuaalisuuteen; Mailer hyökkää metaforilla NASA:a vastaan ja niin edelleen. Hyvällä syyllä voi kysyä, ovatko tällaiset rinnastukset Mailerin lähisokeutta, itseironiaa, impotenssin ilmausta vai kaikkea edeltä.

Symbolisella tasolla itsereflektio on yhtenäistä omakuvaa monimutkaistavien tekijöiden pohdintaa. Omakuva on rakennelma, jonka osat tulevat muualta. Symbolisena tuotteena se on välttämättä epäyhtenäinen, monen näkökulman ja minuuden riitaisa liitto, joka heijastaa kielen perustavaa puutteellisuutta. Kirjoittaminen on tältä kannalta painiskelua olennaisen kyvyttömyyden kanssa, jossa kuvastaan ei saa näköistä. Mailerin proosan itsetietoisuus on Lehtimäen mukaan tämän fragmentaarisuuden ja kyvyttömyyden korostamista tai dramatisointia. Poetiikka tarkoittaa tässä yhteydessä kirjallisten keinojen järjestelmää, joka taittaa suoraa heijastetta kirjailijan ja teosten tekijähahmojen välillä.
Shlomith Rimmon-Kenanin mukaan itsetietoiset ja itseensä viittaavat kirjalliset tekstit etsivät metakielellistä asemaa, josta käsin voitaisiin puhua kielen kyvyttömyydestä saavuttaa viittauksensa kohde. Nämä tekstit "dramatisoivat omat vaikeutensa todellisuuden esittämisessä" (ks. 226). Lehtimäen (s. 201) mukaan Mailerin nonfiktion poetiikan tunnusomainen piirre on refleksiivisen suhteen luominen tekstin lukemisen ja tapahtuman lukemisen välille. Tältä kannalta kirjailijan kuvaukset sanojen kyvyttömyydestä tavoittaa "tapahtuma" kytkeytyvät avantgarden traditioon. Se, miten Lehtimäki hahmottaa Mailerin kamppailun kyvyttömyyden kanssa, tekee Mailerista läpeensä modernin kirjailijan, identiteettiään jatkuvasti uudelleenarvioivan subjektin. Puhe postmodernismista on tässä yhteydessä turhaa (ja Lehtimäki käyttääkin termiä verraten huterasti), sillä Mailerilla ongelma tuntuu palautuvan aina kysymykseen subjektista ja vaihtoehtoisista tavoista hahmottaa todellisuus. Yksi ja jaettu todellisuus on murtunut, ja nyt se "korvataan prismoilla jotka visualisoivat todellisuutta eri kulmista, tai peileillä jotka heijastavat erilaisia diskursiivisia tapoja havaita maailma" (s. 204). Kuvatun tapahtuman esittämistä kaihtava moniulotteisuus kääntyy Mailerilla subjektin roolien ja näkökulmien moneudeksi. Kyvyttömyydestä kuvata tapahtumaa tuleekin kuvaus kirjailijan yrityksestä kuvata. Onko niin, että kyvyttömyydestä tulee Mailerilla jos ei henkilökohtainen niin ainakin subjektin ongelma, ja avantgardistisesta pyrkimyksestä 
kielen uuteen löytämiseen vieläpä minän jälleenrakennusprojekti (s. 254)?

Tekstin itsetietoisuus voidaan määritellä tässä yhteydessä uudelleen niin, että omakuvaa luodaan hallitusti, vaikka se osoittautuisikin epäyhtenäiseksi tai -onnistuneeksi. Tekstin itsetietoisuus on toisin sanoen tekijän itsetietoisuutta tekstin symbolisesta fragmentaarisuudesta. Lehtimäki vähintäänkin vihjaa, että fragmentaarisuus palaa tekijän haltuun Mailerin poetiikassa, ja enemmänkin: toiseus "ei niinkään ole merkki fragmentoitumisesta (...) vaan mahdollisuudesta nähdä erilaisia ja virtaavia persoonallisuuksia itsessä.”. Persoonallisuuksien moneutta pitää yhdessä tekijän ote ("authorial vision and textual organization", s. 184), jolloin tekijä nousee ilmeisesti uudelle tasolle, itselleen läsnäolevaksi subjektiksi äänten, roolien ja näkökulmien moneuden ulottumattomiin. Tämä ainakin selittäisi, miksi silloinkin, kun tekijä äänineen näyttäisi olevan poissa teoksesta (kuten Mailer Pyövelin laulussa), hänet nähdään "vahvasti läsnä" teoksen keskiössä (ks. 283).

Mistä kumpuaa tämä "viimeaikainen itserefleksiivisyyden renessanssi" (s. 89), josta Lehtimäki kirjoittaa? Itsereflektiolla on ollut keskeinen osa kielellisen merkin määrittelyssä viimeistään Descartesista eteenpäin. Sitä on jopa pidetty ilmaisun merkitsevyyden ja referentiaalisuuden mahdollisuuden ehtona. Kun tai ennen kuin käsitettä käytetään 2000-luvulla, olisi syytä pohtia tarkemmin, mistä se on oikein peräisin ja miten se rajoittaa

merkityksenmuodostumisen analyysia - ja myös käsityksiä siitä, mikä on kirjallista. Jotain ironista on siinä, miten yhtäältä kuvitellaan, että Descartes on jätetty kauas taakse, ja toisaalta kirjallisen tunnusmerkiksi nostetaan itsereflektio, jota luonnehditaan niin kuin referoitaisiin Descartesin määritelmää cogitolle (tai Fichten määritelmää "Minälle"). Lehtimäen tutkimuksen ansioihin kuuluu, että se epäröi samastaa kirjallista itsereflektioon. Oireellista kuitenkin on, että Lehtimäki torjuu dekonstruktion muuten metodologisesti suvaitsevasta tutkimuksestaan, sillä juuri dekonstruktion piirissä on käsitelty sitä, voiko kieltä ja "kirjallista" ajatella sitoutumatta filosofiseen itsereflektion käsitreeseen. Itsereflektion logiikan purkamisen myötä voisi kysyä Lehtimäen tutkimusta suoremmin, mitä Mailerin teoksissa ei voi palauttaa osaksi tekijän identiteettiprojektia.

\section{Teemu Ikonen}




\section{Metafiktion käsitteen juurilla}

Mika Hallila: Metafiktion küsite. Teoreettinen, kontekstuaalinen ja historiallinen tutkimus. Joensuu: Joensuun yliopiston humanistisia julkaisuja 44. Joensuun yliopisto 2006. $242 \mathrm{~s}$.

Mika Hallilan väitöskirja Metafiktion $k \ddot{a}$ site on teoreettinen, kontekstuaalinen ja historiallinen tutkimus käsitteestä, joka rantautui 1970-luvun alussa kirjallisuudentutkimukseen. Hallilan mukaan metafiktion käsitettä käytettiin ensimmäisen kerran vuonna 1970, jolloin William Gass määritteli sen teoksessaan Fiction and Figures of Life. Muotoilussaan Gass totesi, että "metafiction is fiction which draws attention to itself as artefact to pose questions about the relationship between fiction and reality" (s. 110). Samalla hän liitti monet antiromaaneiksi kutsutut teokset metafiktioon. Myöhemmin Gassin metafiktion määritelmä on siirtynyt klassikoiksi nousseisiin metafiktiotutkimuksiin, kuten Patricia Waughin ja Linda Hutcheonin 1980-luvulla julkaisemiin teoksiin.

Hallilan tutkimuksen pontimena on huomio siitä, että monissa aiemmissa metafiktiotutkimuksissa "metafiktion käsitteen määritelmä jätetään elastiseksi, avoimeksi, hämäräksi ja epäselväksi" (s. 10). Niissä myös nojaudutaan "liiaksi postmodernismia koskeviin kysymyksenasetteluihin ja käsityksiin" (s. 10). Hallila lähtee paikkaamaan näitä ongelmia. Erit- täin vaikea tehtävä on määrä toteuttaa erityisellä kontekstuaalisella analyysilla, jossa "osoitetaan käsitteen synty-yhteys, analysoidaan sen sisältöä ja osoitetaan sille sovellusalueita - lisäksi luodaan itsenäistä teoreettista kontribuutiota teoriaan, jossa käsitettä on määritelty" (s. 22). Taustaolettamuksiaan Hallila selvittää hyvin tarkasti. Kontekstuaalisessa käsiteanalyysissa pyritään luomaan synteesi metafiktion käsitteen käyttöyhteyksistä sekä lisäämään sen "selitysvoimaa" (s. 10). Toisaalta valitettavan avoimeksi tutkimuksessa jää, minkälaiseen käsitykseen kontekstista loppujen lopuksi sitoudutaan, kun määritellään metafiktion kaltaista vaikeaa käsitettä.

Erityisesti Morris Weitzin klassiseen käsitetutkimukseen Theory of Concepts (1988) nojautuen Hallila määrittelee tutkimuksensa sekä käsiteanalyyttiseksi että käsitehistorialliseksi. Käytännössä väitöskirjassa eritellään 1970-luvulta lähtien käytyä kirjallisuusteoreettista keskustelua metafiktion käsitteestä ja selvitetään käsitteen kytköksiä modernistisen, postmodernistisen ja realistisen romaanin teoriaan sekä estetiikkaan. Lisäksi teoriaerittelyjen lomassa analysoidaan muutamia metafiktioksi tunnistettavia romaaneja. Yksi tärkeä osa työstä on metafiktion käsitteen historiaa esittelevä luku. Tutkimuksen loppupuolella valotetaan myös metafiktion yhteyttä romaanin lajityypilliseen refleksiivisyyteen sekä erityisesti Hutcheonin ja Waughin teorioiden innoittamana pohditaan metafiktiota lukemisen näkökulmasta. Metafiktion 
lukemistapahtuman kompleksisuutta Hallila valottaa tukeutumalla Louise M. Rosenblattin, Wolfgang Iserin ja Roman Ingardenin teorioihin.

Hallilan teoksen lukija saattaa lähtökohtaisesti odottaa tutkimukselta jonkinasteista lajiteoreettista katsausta metafiktioon. Tutkimuksessa kyse ei kuitenkaan ole lajitutkimuksesta siinä mielessä, että väitöskirjassa hyödynnettäisiin lajiteorioita. Metafiktion suhde lajiteoriaan nostetaan lyhyesti esille, mutta jäädään suhteellisen deskriptiiviselle tasolle: todetaan, kuinka metafiktio on "keino, elementti, romaanityyppi, 'genre'. Riippuu kirjailijoista ja lukijoista, mihin sitä lopulta käytetään" (s. 199). Hallilan määrittelyt perustuvat pitkälti postmodernistiseen romaanikäsitykseen. Hän korostaa sitä, kuinka juuri postmodernistinen romaani on keskittynyt fiktion kielellis-konstruktivistiseen luonteeseen ja nostanut esille problemaattisen suhteen todellisuuteen. Samalla hän kuitenkin korostaa, että metafiktiivisyyttä on esiintynyt aikaisemmin, kuten juuri realismin kirjallisuudessa. Suhteellisen avoimeksi työssä jää, missä erilaisissa funktioissa metafiktiota on eri aikojen kirjallisuudessa ollut.

Hallilan aineisto on erittäin laaja. Paitsi että mukana on runsaasti metafiktiota koskevaa, lähes poikkeuksetta angloamerikkalaista teoriakirjallisuutta, myös kaunokirjallisuusluettelo on pitkä. Analyysikohteiksi valittujen kirjojen lista ei ole yllättävä, sillä siihen kuuluu tutkijan määritelmän mukaan "pääasiassa paradigmaattisia metafiktioita ja kanoni- soituja postmodernistisia teoksia" (s. 22), joita ovat suosineet myös aikaisemmat metafiktiotutkijat. Näiden lisäksi Hallila on valinnut analyysiin "muutamia romaaneja, jotka eivät esiinny kohteina mainituissa teorioissa tai tutkimuksissa" (s. 22). Kaunokirjallisuusluettelossa on niin suomalaisia kuin ulkomaisiakin teoksia, joiden ajallinen kaari kattaa satojen vuosien ajanjakson.

Varhaisimmat aineistoon valitut teokset ovat kiinalainen muutosten kirja I Ching sekä Laurence Sternen klassikko Tristram Shandy: Elämä ja mielipiteet (1759-1767), kun taas nuorimmat aineistoon päässeet teokset ovat ilmestyneet viimeisen vuosikymmenen aikana. Keskeisimpään rooliin tutkimuksessa ovat päässeet John Barthin, Jorge Luis Borgesin, Italo Calvinon ja Umberto Econ teokset. Suomalaisista kaunokirjallisista teoksista Hallila viittaa lähes yksinomaan Juha K. Tapion esikoisromaaniin Franskensteinin muistikirja (1996). Tosin Hallila analysoi myös - lajikysymystä problematisoimatta - yhdessä kohdin tutkimustaan Kari Aronpuron runoa kokoelmasta Pomo:n lumo (2002). Olisiko tämän runon kohdalla kyse metalyyrisyydestä pikemmin kuin metafiktiosta?

Yhteensä Hallila mainitsee keskeisimpinä analyysin kohteinaan 26 kaunokirjallista teosta. On hyvä, että mukaan on otettu kanonisoituja metafiktioita. Myös kotimaisen ja ulkomaisen kirjallisuuden rinnakkaiselo on positivista. Kuitenkin tutkimuksen ongelmaksi nousee eriaikaisen aineiston mukanaolo, jota olisi voinut 
dokumentoida tarkemmin. Aineisto on eri vuosisadoilta ja eri periodeilta (jopa eri mediumit ovat esillä, kun viitataan myös hypertekstien metatekstuaalisuuteen), ja niinpä olisi ollut syytä reflektoida vieläkin kriittisemmin ja tarkemmin sitä, minkälaisia erilaisia muotoja metafiktiivisyys saa eri aikoina tehdyissä kaunokirjallisissa teoksissa ja miten yksittäisen teoksen synty- ja lajikonteksti vaikuttaa kunakin aikana ilmenevään metafiktioon. Hallila kyllä korostaa moneen otteeseen, kuinka kokonaisuudessaan metafiktiivinen romaani on eri asia kuin se, että romaanissa on vain yksittäisiä metafiktiivisiä katkelmia.

Hallilan väitöskirjassa on paljon tuttua lukijalle, joka on perehtynyt hänen teksteihinsä aikaisemmin. Hallila on julkaissut artikkelimuodossa osia väitöskirjastaan esimerkiksi Kirjallisuudentutkijain vuosikirjassa 54 (2001) ja Avain-lehden numerossa $1 / 2005$. Tässä tutkimuksessa tutut tekstit on osittain laitettu uuteen kontekstiin. Väitöskirja tarjoaa keskitetyn kuvan siitä, minkälaisissa yhteyksissä metafiktion käsitettä on käytetty ja miten se on kehittynyt kirjallisuudentutkimuksessa viimeisen reilun 30 vuoden aikana. Yksittäiset teosluennat, erityisesti Juha K. Tapion Frankensteinin muistikirjasta, olivat itselleni teoksen mielekkäintä antia.

Hallilan tutkimus on parhaimmillaan, jos lukija haluaa kerrata metafiktion käsitteen historiaa. Tutkimus toimii hyvin myös eräänlaisena metafiktiotutkimuksen hakukirjana jo tarkan henkilöhakemistonkin ansiosta. Työn lukemista haittaa joskus sen alkumetreillä toisto: Hallila kertoo lukuisia kertoja, mitä tutkii, minkälainen turkimuksen rakenne on ja mitä pääluvut tulevat sisältämään. Kiitokseksi on sanottava, että työtä on helppo lähestyä, sillä Hallila kirjoittaa selvää asiasuomea, jossa on esseistisen kepeä ote. Hän jättää historiallisesti muuntuvan metafiktion käsitteen avoimeksi ja välttää näin sulkemasta hermeneuttista kehää.

\section{Outi Oja}




\section{Kapitalismikritiikin paluu}

Jussi Ojajärvi: Supermarketin valossa. $K a$ pitalismi, subjekti ja minuus Mari Mörön romaanissa Kiltin yön lahjat ja Juha Seppälän novellissa "Supermarket". Helsinki: SKS 2006. $391 \mathrm{~s}$.

Väitöskirjansa alussa Jussi Ojajärvi luo katsauksen viime vuosikymmenten suomalaisen kirjallisuuden keskeisiin virtauksiin ja teemoihin. Naiskirjallisuuden piirissä on käsitelty esimerkiksi sellaisia kysymyksiä kuin naisiin kohdistuva syrjintä, äidin ja tyttären välinen suhıde, naisen scksuaalinen halu ja nuorten naisten suhde äitiyteen. Mieskirjallisuuden edustajat ovat puolestaan pohtineet perinteisten maskuliinisuuksien problematisoitumista sekä miesten ahdistusta ja heidän suhdettaan emansipoituviin naisiin. Usein näihin sukupuolen kategoriaan kiinnittyneisiin virtauksiin on liittynyt identiteettikysymysten tarkasteleminen. Identiteettitematiikkaa on kirjallisuudessa käsitelty myös suhteessa yhteisöllisyyden asemassa tapahtuneisiin muutoksiin, monikulttuurisuuteen ja muihin postmodernin teemoihin. Lisäksi viime vuosikymmenten kirjallisuudessa on runsaasti omaelämäkerrallisia, metakirjallisia sekä fiktion ja faktan välistä rajaa sekoittavia teoksia.

Kriitikot ja kirjallisuudentutkijat ovat tunnistaneet edellä mainittujen virtausten olemassaolon. Jos kriitikoita ja tutkijoita on uskominen, kirjallisuutemme ei kuitenkaan olisi viime vuosikymme- ninä juurikaan kosketellut yhteiskunnan läpikapitalisoitumisesta johtuvia kysymyksiä. Entä itse kaunokirjalliset tekstit? "Eikö kirjallisuutemme ole huomannut sitä, että yleisesti ottaen 1990-luvun ja 2000-luvun alun mittaan jouduttiin yhä selvemmin törmäämään niin sanottujen markkinavoimien vaikutukseen elämänpiireissä?", kysyy Ojajärvi (s. 14) ja vastaa kysymykseensä, kuten odottaa sopiikin, myöntävästi. Hän mainitsee Leena Krohnin, Mari Mörön, Hannu Raittilan, Juha Ruusuvuoren ja Juha Seppälän esimerkkeinä kirjailijoista, jotka ovat käsitelleet nykyistä talouden ehdoilla toimivaa yhteiskuntaa kriittisesti. Heidän tuotannostaan hän on valinnut tutkimuksensa kohteeksi Seppälän novellin "Supermarket" (1991) ja Mörön romaanin Kiltin yön lahjat (1998).

Ojajärven esittämät kriittiset huomautukset kirjallisuudentutkimuksesta pitänevät pääosin paikkansa. 1980- ja 1990-luvun vaihteen jälkeen yhteiskunnan, talouden ja kapitalismin käsitteet todella putosivat paljolti pois suomalaisten kirjallisuudentutkijoiden käsitteistöstä. Sen jälkeen heillä ei, Ojajärvi (s. 16-17) huomauttaa, ole ollut välineitä tarttua nykykirjallisuuden kapitalismikriittisiin puoliin. He eivät ole osanneet kysyä kirjallisuudelta sellaisia kysymyksiä, joiden kautta nuo puolet olisivat tulleet esiin. Sikäli kuin yhteiskunta on otettu viime vuosina huomioon kirjallisuudentutkimuksessa, se on tapahtunut pääosin sukupuolen kategorian ja postmodernin tematiikan pohjalta. Tämä yleistys pätee 
myös kulttuurin käsitteellä työskentelevään kirjallisuudentutkimukseen, joka lähti maailmalla liikkeelle osaksi marxilaisin ja yhteiskuntakriittisin tunnuksin, mutta josta tällaiset tunnukset haalistuivat sittemmin pois. Ojajärven tutkimuksen eittämätön ansio on siinä, että hän tuo edellä mainitut käsitteet takaisin kirjallisuudentutkimukseen ja herättåä samalla henkiin kirjallisuudentutkimuksen "emansipatorisen" funktion sanan yhteiskuntakriittisessä mielessä. "On valvottava, miten raha muovailee kulttuuria ja subjekteja, sillä ellemme niin tee, on epätodennäköistä, että voimme välttyä tulemasta rahan määrittelemiksi", kirjoittaa Ojajärvi (s. 18) luonnehtien samalla näkemystään ticteenalansa kriittisestä tehtävästä yhteiskunnassa.

Vaikka kirjallisuudentutkimuksen yhteiskuntakriittinen funktio on ollut jonkin aikaa talvilevolla, Ojajärven työ ei ole vailla edeltäjiä Suomessa. Subjektin problematiikasta on viime vuosikymmeninä kirjoitettu paljon niin Suomessa kuin maailmallakin, joskin se on lähinnä tapahtunut sukupuolen, modernisaatioteorian tai postmodernin teemojen pohjalta. Ojajärven työssä subjektin problematiikkaa tarkastellaan konkreettisesta yhteiskunnallisesta näkökulmasta; tutkimus on kiinnostunut siitä, miten kapitalismi asettaa ehtoja yksilöiden toiminnalle ja minuuden rakentumiselle ja miten se muokkaa heidän subjektiviteettiaan.

Näin Ojajärven tutkimus liikkuu marxilaisvaikutteisen kirjallisuudentutkimuksen peruskysymysten äärellä. Mainit- tua kysymystä pohtivat aikoinaan Georg Lukács, Theodor W. Adorno ja Lucien Goldmann. Sitä käsiteltiin myös 1960ja 1970-luvun marxilaisessa teoriassa, ja 1980-luvun alussa Fredric Jameson tarkasteli sitä lähinnä Louis Althusser'n ideologiateorian ja Jacques Lacanin subjektikäsityksen pohjalta. Lukácsia ja Goldmannia lukuun ottamatta nämä tutkijat esiintyvät Ojajärven työn lähteinä. Suomalaisista lähteistä Ojajärvi pitää tärkeänä Pertti Karkaman teosta Kulttuuri ja demokratia (1998), joka crittelee poleemisesti nykyistä uusliberalistista kapitalismia. Samoin historioitsija Juha Siltalan lukuisat tutkimukset kuuluvat Ojajärven työn lähteisiin. Voitto Ruohosen laaja tutkimus Paha meidản kanssamme. Matti Yrjänä Joensuun romaanien yhteiskuntakuvasta (2005) ei ehtinyt vaikuttaa Ojajärven väitöskirjaan. Ruohosen tutkimus selvittää sitä, miten viime vuosikymmenten suuret yhteiskunnalliset muutokset (kasinotalouden romahtaminen, YYAaikakauden päättyminen, markkinavoimien nousu, hyvinvointivaltion alasajo, syrjäytyminen) kuvastuvat Joensuun romaanien yhteiskuntakuvassa. Kysymykset ovat osaksi samoja kuin Ojajärvellä, joskin Ojajärvi keskittyy spesifimmin tarkastelemaan markkinamekanismien vaikutusta subjektiviteettiin.

Teoreettis-metodologisesti Supermarketin valossa sijoittuu sosiologisen, psykoanalyyttisen ja kulttuurintutkimuksellisen kirjallisuudentutkimuksen piiriin. Sosiologisesta käsitteistöstä ja teoriasta tutkimus käyttää erityisesti hyväksi ka- 
pitalisminteorioita, marxilaista tavaraanalyysiä, niin ikään marxilaista tavaramuodon yleistymisen (commodification) käsiteträ, esineistymisteorioita sekä luokkateorioita. Tutkimuksessa esiintyvä luokan käsite on lähinnä peräisin Marxilta, Max Weberiltä ja Pierre Bourdieultä. Psykoanalyyttisestä teoriaperinteestä tutkimus nostaa esiin erityisesti Freudin, Melanie Kleinin ja D.W. Winnicottin, mutta useissa yhteyksissä tekijä nojautuu myös Michel Foucault'n näkemyksiin subjektista.

Supermarketin valossa on erilaisia lähestymistapoja syntetisoiva tutkimus. Tekijä on onnistunut muodostamaan näistä aineksista toimivan käsitteellisen kokonaisuuden, jolla hän analysoi tutkimuskohteeksi valitsemiaan tekstejä. Tutkimuksen rakenne on sikäli poikkeuksellinen, että tutkimuksen alussa ei esitellä kokonaan teoreettis-metodologista välineistöä. Johdanto-luvussa Ojajärvi määrittelee vain lyhyesti kapitalismia ja kontekstualisoivaa lukutapaa. Tämän jälkeen hän siirtyy tarkastelemaan Seppälän novellia "Supermarket" (2. luku), minkä jälkeen hän esittelee yksityiskohtaisemmin subjektiteoriaa (3. luku). Luvuissa 4-8 analysoidaan sitten Mörön romaania, mutta näissäkin luvuissa kehitellään sitä teoreettis-metodologista välineistöä, jolla tuo analyysi suoritetaan.

Ojajärvi itse perustelee tutkimuksensa epätavallista rakennetta sillä, että hän "haluaa säilyttää dialogin teorian ja aineiston välillä’” (s. 23); samoin hän sanoo halunneensa jättää näkyviin osan työn prosessiluonteesta. Tällaiset huomautukset nostavat esiin kysymyksen tutkimustavan (tutkimusprosessin) ja esitystavan (tulosten esittämisen) välisestä suhteesta; esitystavanhan ei välttämättä tarvitse jäljitellä tutkimustapaa, jos se ei ole tarkoituksenmukaista. Ojajärven esitystapa jäljittelee tutkimusprosessia siinä mielessä, että Seppälän ja Mörön tekstejä koskevan esiluentansa pohjalta hän syventää työssään luku luvulta näkemystään näistä teksteistä, erityisesti Mörön romaanista. Pidän tällaista rakennetta perusteltuna. Jos tekijä olisi työnsä alussa esitellyt kaikki teoreettis-metodologiset valintansa, hänen tutkimuksensa alkupuoli olisi ehkä muodostunut turhan raskassoutuiseksi ja tällaisen abstraktin luvun yhteys Seppälän ja Mörön teksteihin olisi voinut jäädä lukijalle monin paikoin epäselväksi. Ojajärven valitsema rakenne palvelee lukijan etuja.

Seppälän novellia käsittelevässä luvussa (s. 39-75) tekijä esittää, että kyseinen "novelli tematisoi subjektienvälisen romahduksen". Romahduksen subjektien välisissä suhteissa aiheuttaa kulutus ja asenne, jota Ojajärvi kutsuu narsistiseksi konsumerismiksi. Niinpä novellin kertojaksi määrittyy, tekijä jatkaa, kapitalisti, joka kutsuu subjekteja ja rahaa markkinoille kuluttamaan ja nauttimaan kuluttamisesta. Lisäksi novellissa on asenteellisesti kertojaa ylempi taso, sisäistekijä, joka suhtautuu kertojaan ironisesti ja joka tuo novelliin kapitalismikriittisen sävyn, vaikka tekijän mukaan konkreettisia todisteita sisäistekijästä on hankala antaa. 
Seppälän novellissa kapitalismikriittinen tematiikka on esillä avoimesti. Mörön romaanin osalta tilanne on hieman toisenlainen; se "reagoi, vaikkakin ehkä 'tietämättään', markkinatalouden kasvavaan hegemoniaan, yhteiskunnan liikahdukseen kohti entistä markkinaliberaalimpaa mallia" (s. 115). Ihmisten välisten suhteiden muuttuminen osto- ja myyntitapahtumiksi ilmenee romaanissa muun muassa siinä, että 6-vuotiaan päähenkilön, Siian, äiti on seksiteollisuuden palveluksessa ja että hän antaa tyttärelleen erilaisia tavaroita, "kiltin yön lahjoja", vastineeksi siitä, että hän on jatkuvasti poissa tämän luota. Siia kasvaa alaluokkaisessa ympäristössä, jossa naiset joutuvat groteskilla tavalla myymään itseään miehille ja jossa miehet hoitavat, toisinaan väkivaltaisestikin, "bisneksiään".

Ojajärvi ei aina tee selvää eroa temaattisen luennan ja symptomi-luennan välillä. Tämän erottelun avulla voi sanoa, että osittain Mörön romaani nostaa temaattiselle tasolle markkinavoimien nousun ja hyvinvointivaltion alasajon jälkeistä yhteiskunnallista todellisuutta, mutta osittain tuo todellisuus myös ilmenee romaanissa tekijän sitä tietoisesti tarkoittamatta. Tässä jälkimmäisessä mielessä Mörön romaanista on löydettävissä merkkejä tai symptomeja nykyisestä yhteiskunnallisesta todellisuudesta, minkä paljastamiseksi tarvitaan symptomi-luentaa. Ojajärvi soveltaa työssään näitä molempia lukutapoja. Paikoitellen hän tuntuu jopa ylitulkitsevan Mörön romaania eli hän löytää kapitalismitematiikkaa sieltäkin,

missä varovaisempi tutkija harjoittaisi lähinnä symptomiluentaa.

Kaiken kaikkiaan Ojajärvi on tehnyt erinomaisen ja merkittävän tutkimuksen, joka palkitsee monin verroin lukijansa. Tutkimuksen loppuun on vielä sijoitettu kiintoisa katsaus (s. 277-304) nykyiseen suomalaiseen kapitalismikritiikkiä edustavaan romaanikirjallisuuteen. Vaikka draamakirjailijat (Pasi Lampela, Reko Lundán, Arto Salminen, Johan Smeds, Jouko Turkka) jäävät sen ulkopuolelle, Ojajärvi saa lukijan vakuuttuneeksi siitä, että hänen valitsemallaan käsitteistöllä kirjallisuudentutkija voi saada paljon irti nykykirjallisuudesta.

\section{Erkki Sevänen}




\section{Pikarijäkälän runoilija}

\author{
Liisa Enwald: Pohjajään ilo. Helvi Juvosen \\ runoudesta. Helsinki: SKS 2006. 379 s.
}

Helvi Juvosen (1919-1959) lyriikasta on ennen Liisa Enwaldin tutkimusta kirjoitettu vain artikkeleita ja jokunen opinnäytetyö. Enwaldin lähes 400-sivuinen opus magnum on oivallinen tarkkuudessaan, ja aineslähteenä se on aarrearkku.

Helvi Juvosesta on ilmestynyt kahdenlaisia tutkimuksia: tuotantoa joko selitetään biografian avulla tai biografia sysätään kokonaan syrjään. Liisa Enwaldin ratkaisu on selväpiirteinen. Teoksen lähtökohdat ovat toiset kuin edeltäjien: runojen tulkinta on pääasia, ja niukat maininnat Juvosen yksityiselämästä ovat yleensä päätyneet loppuviitteisiin. Matti Palmin laaja lisensiaatintutkiclma (1975) ja eräät muut hänen tekstinsä perustuvat tarkoille tiedoille kirjailijan elämästä. Sama pätee Juhani Salokanteleen teokseen Linnasta Saarikoskeen (1993). Palm ja Salokannel piirtävät kuvan anemian ja muiden sairauksien, asunto-ongelmien ja työttömyyden vaivaamasta kirjailijasta, jota satunnaiset työt suomen ja latinan opettajana eivät pelastaneet kroonisesta rahapulasta ja aliravitsemuksesta. Palm ja Salokannel eivät aina osoita, mikä on syytä, mikä seurausta. Esimerkiksi Juvosen poikkeava seksuaalinen suuntautuminen oli keskeinen tekijä tässä ongelmakentässä, olihan se tuolloin ankarasti paheksuttua. Pohjajäätä-kokoelman viimeinen säe Kootuissa runoissa on vetoomus armotto- mille ihmisille: "Nyt ihmiset, ihmistä armahtakaa."

Juvosen lyriikka, joka on totuttu sijoittamaan modernismin kärjen tuntumaan, on alkanut viime aikoina painua taka-alalle, kuten on aiheetta tapahtunut myös esimerkiksi Kaarlo Sarkian tuotannolle. Juvosen runoja on aiempina vuosikymmeninä luettu ja lausuttu paljon, ja seuraavat säkeet kuuluvat yhä Suomen lyriikan tunnetuimpiin: "Jäkälä nosti pikarinsa hauraan:/ Nyt malja elämämme rikkaudelle." Säepari osoittaa Juvosen ilmaisun ja maailmankuvan tärkeimmät ainekset. Puhujan jäljittelemättömän äänen läheisin kansainvälinen esikuva on Emily Dickinsonin lyriikka. Kiteytys ja paradoksi ovat kummankin runojen tunnuksia. Liisa Enwald paljastaa Juvosen lyyrikonkuvan yhden ydinaineksen analysoidessaan "Runkojen lomasta" sarjaa, johon "Pikarijäkälä" sisältyy: Siinä "luonnon osat ovat miniatyyrisiä ja nähdään kuin häivähdyksenä, puiden välistä tai maan tasalta. Sarja näyttää puhujan täsmällisen havainnoinnin ja sen, miten mikrokosmos kätkee avaraa."

Teos on antoisa ja mielenkiintoinen, mutta se herättää eräitä kysymyksiä.

Enwaldin ensisijaisena tutkimuskohteena ovat Helvi Juvosen kuusi runoteosta, joista yksi on postuumi, ja postuumi proosakirja Pikku Karhun talviunet. Tärkeimmän kohteen eli Koottujen runojen rinnalla olisi ollut paikallaan käyttää alkuperäiskokoelmia, joiden nimet eivät nyt edes näy lähdeluettelosta. Runojen sijoittuminen alkuperäisteoksissa eri osas- 
toihin olisi kannattanut panna merkille tulkinnassa, sillä osastot eivät käy ilmi Kootuista. Juvosen lehti- ja muita kirjoituksia olisi voinut hyödyntää nykyistä enemmän.

Pohjajään ilossa on tavoitteena lyyrikonkuvan hahmottelu, menetelmänä lähiluku. Rakenne on seuraava: I "Luontoja kulttuurimaiseman kuvat", II "Kipu, risti ja hiljaisuus - keskeisten teemojen tarkkailua" ja III "Rajamaan poetiikkaa". Kokoelmista osastoineen ja lyyrikonkehityksestä ei kuitenkaan synny kattavaa käsitystä, tärkeimmistä teemoista ja yksittäisistä runoista kylläkin.

Tutkimuksessa oudoksuttaa vertailevan otteen useinkin suurpiirteinen käyttö. Enwald mainitsee, että hän suhteuttaa Juvosen lyriikkaa vertauskohdiksi valitsemiensa runoilijoiden teoksiin. Tekstienvälisten yhteyksien osoittaminen ja tulkitseminen olisi antanut jäntevämmän tuloksen. Nyt esimerkiksi Rainer Maria Rilken osuus on huomattavan suuri verrattuna vaikkapa Emily Dickinsonin tai eräiden muiden Juvosen suomentamien runoilijoiden saamaan huomioon. Missä ovat Juvosen runoudelle tärkeät länsimaisen lyriikan klassikot ja antiikin kirjailijat? Sama valikoinnin pulmallisuus jatkuu kirjallisuusvirtauksien osalta. Hyvä, että imagismi on taajaan esillä, mutta mihin ovat unohtuneet eräät muut kauden kirjallisuusvirtaukset? Juvosen yhteyksiä varsinkin ekspressionismiin kannattaisi analysoida.

Pohjajään ilo pitänee lukijan mielenkiinnon vireänä. Ei voi silti olla kysymät- tä, eikö tiivistäminen olisi ollut tekstille eduksi. Se olisi kuitenkin tullut tehdä taiten, jotta se ei olisi vienyt mukanaan sellaista, mikä on tutkijan esitystavassa rikasta ja omintakeista. Enwald pysähtyy kuuntelemaan, kysymään ja pohtimaan, mikä tekee hänen parhaissa tulkinnoissaan oikeutta kohteelle. Tekstiin jää väljyyttä lukijankin tulla mukaan omine pohdintoineen. Tulkinnat eivät ole kiinni napitettuja, ja ote poikkeaa edukseen niiden kirjallisuudentutkijoiden tyylistä, joiden esitystapa on oppitermein lastattua ja ilmattoman tiivistä.

Väljyyttä ja ilmavuutta olisi voinut karsia erityisesti viimeisessä osassa, jonka nimi on "Rajamaan poetiikkaa". On toki tarpeen eritellä Juvosen tyhjyysteemaa, jota jo Yrjö Sepänmaa piti tärkeänä Pikku karhun talviunista kirjoittamassaan kritiikissä. Tyhjyyttä ja sen voittamista koskeviin Pohjajään ilon lukuihin olisi kuitenkin kaivannut asioiden valottamista filosofian avulla ja myös modernismin teorian kautta. Täsmällinen intertekstuaalisten yhteyksien osoittaminen ja analyysi olisi ollut tässä paikallaan.

Enwaldin näkemyksellisyys ja vivahteiden taju ovat poikkeuksellisia. Hänen tulkintansa jäävät vain harvoin harmillisesti puolitiehen. Helvi Juvosen lyriikka on saanut Liisa Enwaldissa arvoisensa tulkitsijan. Teos on aarrearkku sille, joka etsii syvällisiä analyyseja Juvosen keskeisimmistä runoista. Tutkimus osoittaa harvinaista herkkyyttä, oivallusta ja ilmaisukykyä. Pobjajään ilo on esimerkki sellaisesta luennasta, jota on kyselty 
ja odoteltu. Varsinkin Juha Rikama on syystä toivonut tutkimukselta ja kirjallisuudenopetukselta paneutumista peruskysymyksiin, kuten rakenne- ja erityisesti teema-analyysiin. Läheskään kaikki teorian ja käsitteiden muoti-ilmiöt eivät auta kaunokirjallisuuden luovassa luennassa. Teorian ja lukutapojen päiväperhoset voivat olla monenkirjavia, mutta ne eivät useinkaan edistä lyriikan luovaa luentaa. Pohjajään ilo tekee sen.

\section{Katriina Kajannes}

